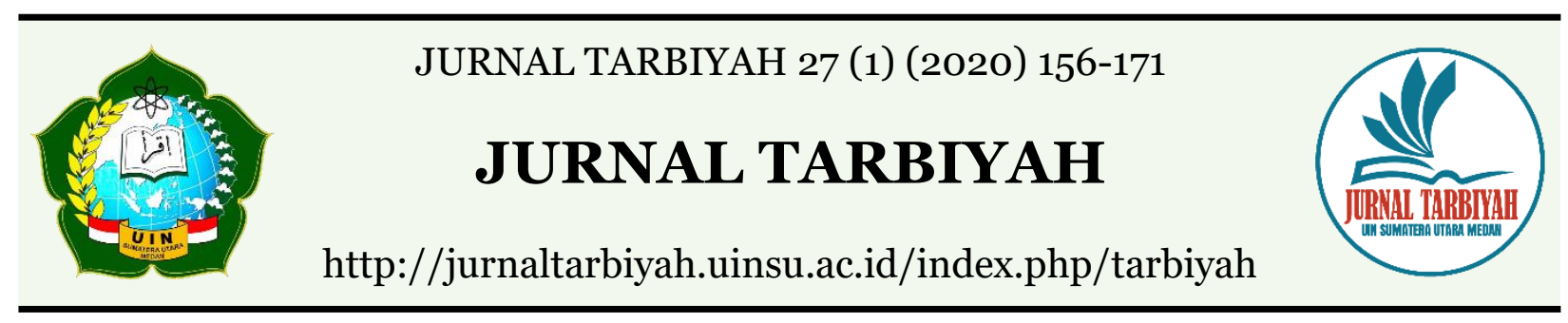

\title{
THE COMPETENCY ANALYSIS OF PRINCIPAL AGAINST TEACHERS IN CONDUCTING DISTANCE LEARNING IN COVID-19 PANDEMIC
}

\author{
Elfrianto $^{1}$, Irfan Dahnial'2, Bahdin Nur Tanjung3 \\ 1,2,3Universitas Muhammadiyah Sumatera Utara \\ Email : ${ }^{1}$ elfrianto@umsu.ac.id, ${ }^{2}$ irfandahnial@umsu.ac.id, 3bahdinnur@umsu.ac.id
}

DOI : 10.30829/tar.v27i1.704

Accepted: April 16th, 2020. Approved: June 25th, 2020. Published: June 30th, 2020

\begin{abstract}
This study aims to analyze the principal's competence towards teachers implementing online learning during the 19th period to save the vital role of education itself, especially the opportunity for the principal as a leader in the school environment to give influence to the teacher in the distance learning process (online), as well as providing safety for many people, especially for students to avoid covid19. This study is a study that uses a literature review method that is where the authors make observations and reviews as well as analyzing the results of previous writings that will become a reference in this writing. The results of this study are: 1) the role of the principal is vital in term of the competencies that must be possessed by a leader in the school environment not only during the COVID19 pandemic but also during ordinary situations; 2) and during such regular activities, the role and Principal competence must be able to provide positive space for teachers to improve competence in term of teaching and learning.
\end{abstract}

Keywords: Principal Competence, Teacher, Covid-19 


\section{INTRODUCTION}

The principal is a functional teacher who is given the task to lead a school where teaching and learning processes are held or where interaction occurs between the teacher giving the lesson, and the student receiving the lesson. This school principal can be said as a leader in the education unit whose job is to run the education unit management led. Moreover, the school principal is a functional teacher who is given the task to lead a school where teaching and learning processes are held, or where there is an interaction between the teacher giving the lesson and the student receiving the lesson. At the operational level, the principal is the person in the forefront who coordinates efforts to improve quality learning.

The principal is appointed to hold the position of responsibility to coordinate joint efforts to achieve educational goals at the school level being led. Of course, the principal is not the only one who is fully responsible for a school because there are still many other factors that need to be taken into accounts, such as teachers, students, and the environment that influences the learning process. However, the principal has a role that significantly influences the running of the existing system in the school. The principal is one of the education components that has the most role in improving the quality of education. The school principal is responsible for organizing education, school administration, fostering other education personnel, utilizing and maintaining facilities and infrastructure as well as supervisors at the school he leads.

Effective principals ensure that their schools allow both adults and children to put learning at the center of their daily activities, such as a healthy school environment, which is characterized by basics like safety and orderliness. Also, a physical quality such as a "supportive, responsive" attitude toward the children and a sense by teachers that they are part of a community of professionals focused on excellent instruction. Principals may be relieved to find out, moreover, that their authority does not wane as others' waxes. Clearly, school leadership is not a zero-sum game. Principals and district leaders influence decisions in all schools; however, they do not lose influence as others gain influence.

In order for schools to achieve their goals ethically and efficiently, the principal must carry out managerial functions such as planning, organizing, directing, motivating, implementing, organizing control, evaluating, and innovating. A good principal is expected to shape the implementation of learning by excellent teachers. If learning in a 
good school will undoubtedly produce good student and teacher achievements. Therefore, this implies that the principal's leadership plays a vital role in proper school management.

Leadership is a process to influence that is carried out by someone in managing their group members to achieve organizational goals. So leadership is a form of strategy or theory of leadership, which is undoubtedly done by people we usually call leaders. Therefore the right leadership style principals can influence and motivate teachers to achieve specific goals especially in the present time as is unusual, now teachers and students lose communication, as usual, more often using learning media, here also principals are required to have competence so that teachers can carry out their tasks online or use technology so that the learning process continues.

\section{LITERATURE REVIEW}

\section{UNDERSTANDING OF THE PRINCIPAL}

The success of educational institutions is highly dependent on the leadership of the school principal. Because the principal as a leader in his institution, he must be able to bring his institution to achieve the goals set, he must be able to see change and be able to see the future in a better globalization life. The principal must be responsible for the smoothness and success of all formal government and management matters to his superiors or informally to the community who has entrusted his students. The principal is a functional teacher given the task of leading the school where the teaching and learning process is held or where there is an interaction between the teacher who is giving lessons and students who are receiving lessons.

A principal is a primary leader in a school building. A good leader always leads by example. A principal should be positive, enthusiastic, have his hand in the day-to-day activities of the school, and listen to what his constituents are saying. An effective leader is available to teachers, staff members, parents, students, and community members. He stays calm in difficult situations, thinks before acting, and puts the school's needs before himself. An active principal steps up to fill in holes as needed, even if it is not a part of his daily routine.

In school institutions, principals, or more popularly, are now referred to as "teachers who get additional assignments as principals." Not those who are fortunate to have seniority, especially by chance. Being recruited to occupy that position, with a rigid and infertile performance, they are expected to become influential personal figures who can be relied on in the context of achieving school goals. In the explanation above, it can 
be concluded that the position of the principal determines the direction of an institution. The principal is the program manager in the school. It is therefore expected that the principal will bring enthusiasm to the teacher's work and build a school culture to improve the quality of education, especially the National Examination.

Principals themselves agree almost unanimously on the importance of several specific practices, according to one survey, including keeping track of teachers' professional development needs and monitoring teachers' work in the classroom (83 percent). Whether they call it formal evaluation, classroom visits, or learning walks, principals intent on promoting growth in both students and adults spend time in classrooms (or ensure that someone qualified does), observing and commenting on what is working well and what is not. Moreover, they shift the pattern of the annual evaluation cycle to one of the ongoing and informal interactions with teachers.

Effective principals work relentlessly to improve achievement by focusing on the quality of instruction. They help define and promote high expectations; attack teacher isolation and fragmented effort; connect directly with teachers and the classroom. Most principals also are responsible for evaluating their teachers' performance following district and state guidelines. An effective school has effective teachers, and the teacher evaluation process is in place to ensure that the teachers are effective. Evaluations should be fair and well documented, pointing out strengths and weaknesses.

However, a good principal should spend as much time in classrooms as possible. He should gather information whenever he visits a classroom, even if it is just for a few minutes. Doing this allows the evaluator to have a more extensive evidence collection of what goes on in a classroom than a principal who makes few visits. A good evaluator always lets his teachers know his expectations and then offers suggestions for improvement if they are not being met.

Many leaders, by nature, have a hard time putting things in others' hands without their direct stamp on it. However, it is vital that a school principal delegate some duties as necessary. Having trustworthy people around will make this easier. A competent school principal does not have enough time to do everything that needs to be done by himself. He must rely on other people to assist him and trust that they are going to do the job well.

\section{PRINCIPAL FUNCTIONS AND ASSIGNMENTS}

The principal is a teacher who gets an additional assignment as a principal. (Sudarman 2002: 145). Although the teacher who has the additional duties of the 
principal is the person most responsible for applying the principles of innovative education administration in the school. As an additional person means the principal's job is that the principal is a teacher, namely as a teaching staff and educator, this means that in the school the principal must have the task of being a teacher who does or gives lessons or teaches a particular field of study or provides guidance. It means the principal occupies two functions, namely as education staff and teaching staff. According to Sudarwan about the types of education personnel as follows:

It was also explained that the principal must at least be able to function as an educator, manager, administrator, supervisor, leader, innovator, motivator. However, along with the development of the age towards globalization, the principal should be able to adjust according to his function as a professional principal.

The principal must be able to: (a) Encourage the emergence of a strong will with enthusiasm and confidence of teachers, staff, and students in carrying out their respective duties. (b) Providing guidance and directing teachers, staff, and students as well as providing encouragement and standing in front for the sake of progress and inspiring schools to achieve goals (Wahjosumidjo, 2005: 105). Thus concluded the principal's task as educators, managers, administrators, supervisors, leaders, innovators, motivators, figures and mediators are outlined below:

(1) Educator, the task of the principal as an educator, must have the right strategy to improve the professionalism of the teaching staff in his school. Creating a conducive climate in schools, giving advice to school residents, giving encouragement to all education personnel, and implementing attractive learning models, such as team teaching, moving classes, and conducting acceleration programs for intelligent students above normal. The headmaster also always strives to improve the quality of learning carried out by each teacher. In this case, the experience factor will significantly influence his professionalism, especially in supporting the formation of an understanding of the teaching staff towards the implementation of their duties.

(2) The principal's manager must have the right strategy to empower education staff through cooperation, provide opportunities for education staff to improve their profession, and encourage all education personnel in various activities that support school programs.

(3) Principal administrator, as the administrator, has a very close relationship with various administrative management activities that are recording, compiling, and documenting all school programs. To support their ability in administration, the principal 
must have the ability to manage the curriculum, student administration, manage personnel administration, administration of facilities and infrastructure, file administration, and manage financial administration. As a professional principal, the above administrative activities need to be carried out effectively and efficiently to support school productivity.

(4) Supervisor, the tasks of a school principal is to supervise the work carried out by teachers or school administration employees. Supervision is meant to conduct supervision and control to improve the performance of education personnel. It is controlled so that educational activities in schools are directed to the goals that have been set. The principal, as a supervisor, must be realized in compiling and implementing the education supervision program, as well as utilizing the results. The principal's supervision ability can be realized by preparing a class supervision program, developing a supervision program for extracurricular activities, library, laboratory, and examinations.

The role of the principal covers many different areas, including leadership, teacher evaluation, and student discipline. Being a competent principal is hard work and is also time-consuming. A good school principal is balanced within all her roles and works hard to ensure that she is doing what she feels is best for all constituents involved. Time is a major limiting factor for every principal. A principal must become efficient at practices such as prioritizing, scheduling, and organization.

\section{TEACHER COMPETENCE}

The teacher is one of the main factors for the creation of a quality generation of the nation, not only in terms of intellectuality but also in the manner of behaving in society. The teacher plays a vital role in determining the quantity and quality of teaching carried out in class. Teachers, according to Law Number 14 of 2005 concerning Teachers and Lecturers are "professional educators with the main task of educating, teaching, guiding, directing, training, evaluating, and evaluating students in early childhood education, formal education pathways, basic education, and education medium".

The teacher is a professional who has a crucial function, role, and position in achieving the vision of education in 2025, namely creating intelligent and competitive Indonesian people. The role of the teacher is not only teaching but also as a facilitator, motivator, and evaluator, both in terms of knowledge and attitudes of students. So the duties and responsibilities of teachers are not just transferring knowledge to students but 
also are obliged to form students who are characterized by students who have faith, have good morality, are capable of being independent, useful for religion, and the nation.

Competence comes from English, namely competence, which means skills and abilities. Competence, according to Law No. 13/2003 concerning Labor, "is the workability of every individual which includes aspects of knowledge, skills and work attitudes that are under specified standards". According to Santosa's Big Indonesian Dictionary (2015:405) the notion "competence is the power to determine or decide on a thing". In the teaching system, competencies are used to describe professional abilities, namely the ability to demonstrate knowledge and conceptualization at a higher level. This competency can be obtained through education, training, and other experience according to the level of competence.

Sudjana (2004: 17) states that "teacher competence is a basic ability that must be possessed by teachers". According to Sudrajat (2007: 11) that teacher competence is a description of what a teacher should be able to do in carrying out his work, both in the form of activities in behavior and intended outcomes. Based on the description above, it can be concluded that teacher competencies are abilities in the form of knowledge, skills, and attitudes that are lived and mastered by teachers in carrying out their professional tasks.

Competent teachers are teachers who carry out the functions and objectives of the school and have the competencies required for teachers to carry out their duties as well as possible. In other words, competent teachers are professional teachers. Teacher competition is a useful tool for providing the best service so that students feel satisfied in the learning process. Teacher competencies are divided into four types, which are many different classifications between experts but have the same core.

Pedagogical competence is the ability to manage student learning, which includes an understanding of students, designing and implementing learning, evaluating learning outcomes, and developing students to actualize their various potentials. Santoso (2013: 90) argues that pedagogic competence is the ability to manage learners which includes the scope of (1) The ability to understand the characteristics of students; (2) Ability to carry out learning; (3) The ability to evaluate learning outcomes; and (4) the ability to develop the potential of students.

Personality competence is the ability of teachers with a steady, stable, mature, wise, and authoritative personality, an example for students and good morals. The scope of personality competencies includes 1) The ability to display personalities that are steady, 
stable, mature, wise and wise and authoritative 2) The ability to present oneself as a person of noble character and can be made an example for students; and 3) The ability to evaluate one's performance and sustainably develop themselves.

Professional competence is the ability to master a broad and deep learning material. The scope of professional competence, namely: (1) The ability to master the material, structure, concepts and scientific mindset that supports subjects; (2) The ability to develop learning material that is taught creatively; (3) The ability to develop professionalism on an ongoing basis by taking reflective action; and (4) The ability to use information and communication technology to develop themselves ".

Based on the description above, it can be concluded that professional competence is the ability of teachers in planning and implementing the learning process. The teacher has the task of directing the learning activities of students to achieve learning objectives. The teacher must always update and master the subject matter presented. Selfpreparation about the material is sought by finding information through various sources such as reading the latest books, accessing from the internet, always following the latest developments and progress on the material presented. Teacher social competence is the ability of teachers to interact socially under their roles as educators, peers, or part of the community. The indicators of teacher social competence are: communicating effectively with students, fellow educators, education personnel, parents, and the surrounding community.

\section{DISTANCE LEARNING}

Distance learning, also called distance education, e-learning, and online learning, a form of education in which the main elements include physical separation of teachers and students during instruction and the use of various technologies to facilitate studentteacher and student-student communication. Distance learning (also referred to as distance education) is training delivered to students or participants who do not gather together regularly in the same place to receive it in person from the trainer. Mostly detailed materials and instructions are sent or made available to students who carry out tasks that are, in turn, evaluated by the trainer. In fact, the teacher and learners may be separated not only geographically but also in time.

Distance learning allows students to take classes whenever and where ever they are. It allows them to fit their learning and education around other responsibilities and 
commitments such as family and work. It also gives students who would not otherwise be able to learn because of time, distance, financial difficulties, and the opportunity to participate. It also has the potential to make less commonly taught subjects available to more learners.

Distance learning can be beneficial, especially for more mature learners who have strong motives for success and are happy to be in charge of their learning. However, successful Distance Learning packages, cutting out the relentless timetable of face-to-face learning, are nonetheless not an easy option for either learner or trainer. Here are some of the advantages and disadvantages:

Table 1 Advantages and Disadvantages

\begin{tabular}{|c|c|}
\hline Advantages & Disadvantages \\
\hline $\begin{array}{l}\text { Easy logistics - all you need is } \\
\text { good communications. } \\
\text { - Lack of overheads such as } \\
\text { classroom and teaching staff } \\
\text { - Students are in control of when } \\
\text { they learn and at what pace. } \\
\text { - It can be more } \\
\text { affordable/possible because } \\
\text { students can fit study around } \\
\text { work. }\end{array}$ & $\begin{array}{l}\text { Time and work associated with } \\
\text { delivering distance learning exceed that } \\
\text { of face-to-face training. } \\
\text { - Administrative support for distance } \\
\text { learning may need to cater to a higher } \\
\text { number of students. } \\
\text { - Some students find learning at a } \\
\text { distance isolating. } \\
\text { - The lack of structure and need for a } \\
\text { high level of motivation/initiative can } \\
\text { be challenging for students. }\end{array}$ \\
\hline
\end{tabular}

Distance learning can be delivered using a variety of techniques and technologies. E-learning is probably the most expensive and cutting edge form of distance learning, but there are other ways of delivering training at a distance that has been used successfully for many years. Methods of delivery include:

- E-learning: Delivering using computers utilizes internet technology and programming, allowing the student to interact with the learning materials via chat rooms, notice boards, video conferencing, etc.

- Television programming: involves a series of television programs that are designed to convey the techniques and theory. These could be broadcast via cable 
or terrestrial channels or provided on videotape or DVD. For many years the Open University in the UK used this technique.

- Written materials: sometimes called correspondence courses, this is textual matter explicitly written for the distance learning course, for example, a workbook involving exercises and tasks, which the participants work through at their speed. By the current online learning model, some students accept online learning because the online learning model is more relaxed, fun, flexible, efficient, concise, practical, fast, precise, safe, easy, and saving time. That way can also be done remotely without gathering in the same place. Besides the other benefits of the learning model in the network are parents can supervise their children learning, make students or teachers become technology literate, accelerate the era of 5.0, improve ability in the field of technology science. Students become more creative in completing their assignments. They can condition themselves as comfortable as possible to learn without formal rules.

On the other hand, there are some critical success factors for distance learning in schools:

1. The trainer needs to be enthusiastic and committed.

2. The team should include excellent administrative support and, depending on the type of materials and delivery methods, using a good design and production staff.

3. The teaching materials must be properly planned, so they are tested and ready in time. Most of the work occurs before the material reaches the students.

4. There must be facilitation and encouragement of learner interaction with both trainers and other learners.

5. The trainer needs to keep in regular contact with all the students.

6. Competent use of any technology used is a prerequisite. It should be fully tested and explained to the students, so they are familiar and comfortable with it.

7. Communication and technical problems should be dealt with as they arise.

8. Trainers need to use a variety of methods for interaction and feedback (e.g. oneon-one and conference calls, snail-mail, email, video, and computer conferencing)

9. Students could keep a diary of their views on progress and course content they submit or share in some way at frequent intervals.

10. It is crucial to have a residential course at least once, preferably at the beginning to help learners settle into the distance learning routine and to give some direction on study techniques. 
They utilize existing technology for usefulness; perhaps it is one of the right innovations and needs to be improved in the digital process, considering the need for mastering information technology systems in developing science in the era of 5.0, which is highly sophisticated. Students can be smarter at using existing technology, and more time at home with family. The answers obtained from the questionnaire about the advantages of online learning being filled out by my friends as many as 121 responses that have been filled out, but we just entered a few here.

The aim of the current online learning model is that we can study at home to avoid the outbreak of COVID-19, to prepare students who are ready to compete in the digital age, the learning process becomes more relaxed, diligently arranging deadlines for working on assignments/learning given material, sending timely assignments, more time to study. For schools or campuses that are accustomed to implementing remote learning every day, but currently, there are still schools in Indonesia that have never or rarely do learning systems in online networks because of the COVID-19 virus, all this is currently mandatory even though it is not possible to inhibit the spread of the virus.

\section{RESEARCH METHOD}

In conducting scientific research, a systematic drafting technique must be carried out to facilitate the steps to be taken. Likewise, what the authors did this in this study is the first step is to conduct a literature study in books that discuss the Theory of Constraints, journals, and research that has been done relating to TOC. The data obtained from this literature study will be used as a reference for making research missionaries. Data collection is done by surveying some literature and finding the validity of the data correctly and is believed to be valid in the previous literature.

\section{RESULTS \& CONCLUSION}

The widespread outbreak of Covid-19 or the Corona virus has become a momentum for teachers to develop distance learning methods. This was conveyed by the Ministry of Education and Culture (Mendikbud:2020) "This is a disaster that occurred on a national scale but this is also an opportunity for teachers to adapt (using online learning)". Those who were initially afraid or reluctant to use this method are currently forced to adapt so that the learning process can be carried out (Ministry of Education and Culture: 2020). From this, we will find out the learning process online and with which 
platforms are suitable ". The distance learning method, said Nadiem, will not be standardized using just one method. According to him, each region was freed to find out and innovate for themselves which method was considered suitable. "It is not a national scale, and it is directly online. This is based on taste, which is the right platform, what method is the request, this is important learning," Exactly there are 6 (six) policies that are clearly explained.

However, the most fundamental thing is to change the way of teaching and learning of students and teachers is a learning policy from home. This home study policy has dramatically changed the habits or behavior of teachers and students so far. How not, so far, the teacher teaches in the classroom the sense of teaching in a school building with a teaching and learning function, supported utilizing supporting the teaching and learning process. (Minister of Education and Culture: 2020).

With this new policy, teachers are made confused because they are still looking for the right pattern of how learning from home can be done. The best way is to do or seek network-based learning. Another name is online learning. This learning is very different from conventional learning that occurs in schools. Teachers and students do not face each other but rather occur remotely, which allows teachers and students to be in different places. Positive learning is beneficial for the continuity of learning in this pandemic. Teachers and students will remain safe in their respective places or homes without having to leave the house and meet face to face.

However, changing patterns or habits is complicated, and changes occur quickly and unexpectedly. Habits that have changed significantly, for example, teachers and students rely heavily on computer devices and internet networks, that is the first. Second, teachers and students must be able to change the style, strategy, or teaching methods. Third, teachers and students must be able to change their communication style during online learning. Many teachers do not pay attention to this third part, namely the lack of understanding and application of teachers in communicating with their students. The teacher usually communicates one or two directions in school, with a face-to-face meeting, direct discussions, and exercises. The teacher will give an explanation and explanation of a material more efficiently, while students will find it easier to understand and discuss directly with the teacher.

This pandemic occurrence has become very difficult to maintain the teacher's communication style habits. Therefore, there is a need to change the style of teacher communication during or during the Covid-19 pandemic. The communication used by the 
owner, which is long-distance in this case, is known as online communication. This communication allows teachers as communicators and students as communicants to communicate via the internet or cyberspace. The goal is, can be controlled remotely, time efficiency can be done anytime and anywhere. Strongly supports government policies in tackling the spread of this pandemic.

Besides, other positive things can be obtained, such as cost efficiency, extensive learning resources, easy management, and data integration. However, there are still many who do not realize the ease of online communication. Teachers and students can do two types of online education. First, Synchronous Online Communication (together) is a communication with the internet that happens simultaneously and in real-time. For example, text chat and video chat (Whatsapp, Messenger, Hangouts). The second type of communication is Asynchronous Online Communication. This type of online communication is the opposite of the first type, which is communication with the internet network but is carried out delayed or not simultaneously.

Of course, this online communication also has many weaknesses besides the positive things offered earlier. First, it does not represent the emotions of the wearer, in this case, the teacher and students. So the teacher is tough in giving understanding to students, and the teacher does not know the extent of the students' understanding level. Second, there is information that is not important or the information obtained will be very much difficult to filter and control so that the information recipient will be confused. Third, it takes much concentration because it does not suit the place and time, so time management must be prioritized. The teacher, as an information facilitator, should be able to build effective online communication.

Effective communication here is communication that is always intertwined between the teacher and students, so that later can lead to a change in attitude or character towards better for students. Accuracy of information is key in creating effective communication. It happens if similarities in understanding, attitude, and language. Messages or information can be received and understood and understood as intended by the communicator (teacher). The message delivered can be approved by the communicant (student). There are no significant obstacles in following up messages or information.

These three things are the elements of effective communication. Therefore, to fulfill these elements of effective communication in online learning, the teacher must do various things. First, create online class rules, including the time and application used. Second, build a pleasant atmosphere for discussion in online classes, although it is rather 
challenging to do but try to do the discussion, whether synchronous or asynchronous. Do not let students who ask questions or need reinforcement not be served. Third, although in online learning, teachers should still use verbal and non-verbal expressions in providing feedback, reward, and punishment. Here you can use emoticons, stickers, or sentences that motivate students. Fourth, the teacher must be able to relate the material to the current or current situation, so that students understand it easily. Fifth, use video or animation that supports the material, so it is not dull.

Besides, in developing communication, the teacher also needs to pay attention to several things. First, use simple language, which is easy to understand and can also motivate students' psychics. Second, the teacher must be able to understand the conditions or circumstances of his students. Third, the meaning of the message or information must be clear and useful. Fourth, the teacher must be able to instill respect and mutual assistance if other students are experiencing difficulties. In this situation, students are helping the teacher in various ways, for example, difficulties in using applications. Fifth, teachers must also instill a democratic spirit in their students. Democracy is demonstrated by providing freedom of mutual input during online learning.

Speaking of the leadership of the school organization, the headmaster is at the forefront of efforts to educate the nation. The school principal is the spearhead in the success or failure of an educational unit that he leads. The principal assumes responsibility for the school environment's comfort and order and the school's residents. The teacher, students, and parents must felt this sense of security and comfort. It includes security and comfort during the Covid-19 emergency response period. The principal plays a vital role as a leader in building an educational atmosphere and ensures that students continue to get meaningful learning, such as elementary, junior high, high school and tertiary teachers who are doing distance learning to their students while continuing to use active learning.

Therefore, I am sure that with the right steps and proper coordination with all schools, the learning and teaching process during the Covid-19 outbreak will run smoothly. A decision that requires students and teachers to learn from home, the principal must be able to transmit the spirit of change to teachers, students and parents quickly, and accurately such as:

(1) Designing curriculum and learning in accordance with the co-19 disaster emergency conditions through optimizing the use of technology (smart class). This step is crucial considering that teaching and learning activities will be carried out by teachers 
and students even though using the remote (online) method. The teachers made detailed and accurate teaching maps of the distribution of material to be carried out / discussed during the Covid-19 pandemic as well as asking teachers between subjects to be able to collaborate and arrange schedules so that the students' workload is not too high and piled up. Besides, based on the circular from the government, the task is not only the aspect of knowledge, so we also incorporate aspects of life skills where students feel online learning must be fun and meaningful.

(2) I would also like to give motivation to the teachers so that whatever obstacles and problems faced by the teacher can be discussed well about the use of online media or the solutions they want to get. Teaching online means that it requires extra energy to prepare material, and so on.

(3) Providing motivational words and appeals so that in this period of boredom, students remain eager to do their activities/assignments at home. Even so, many parents feel stressed and overwhelmed by being impromptu teachers at home for students. Thus the role of teachers and principals is crucial in handling COVID 19 properly for students because the education and health of Indonesian children are the main competitors.

It can be concluded that the principal's role is a virtue in influencing the organizational structure of the school environment, especially in the current 19th council. The role of the teacher becomes vital in this case because it must refer to the instructions of the Minister of Education and Culture to learn from home because the situation is impossible for learning to take place in the school environment. Because education is most important for a country, but the health of students and the safety of students is also the most important in this case because it involves the lives of many people.

\section{REFERENCES}

Anonymous. 2009. School Financial Management. Directorate of Education Personnel, Directorate General, Quality Improvement of Educators and Education Personnel.

Daryanto, Education administration, (Jakarta: Rineka Cipta, 2001) 81.

Ministry of National Education. 2003 and High School (One Model of

Educational Services for Students Who Have Special Intelligence and Talent Potential). Jakarta: Ministry of National Education.

Dharma, Agus. 2003. Principal Competency Standards. Jakarta: Ministry of National Education Staff Training Center.

Mulyasa, E. 2007 Becoming the Principal of the Professional School, 1 (Jakarta: Rosda, 
2010), p. 98

Mulyasa, E. 2007. Becoming a Professional School Principal. Bandung: PT. Teen Rosdakarya.

Hari Sudrajat, School Based Quality Improvement Management, (Bandung: Cipta Cekas Grafika, 2004) 112.

http://aktual-asiddau.blogspot.com/2010/o9/tugas-pokok-dan-fungsi-kepalasekolah.html

https://www.pintar.tanotofoundation.org/peran-kepala-school-di-saat-pandemi-covid$19 /$

https://radarbali.jawapos.com/read/2020/04/24/190653/online-learning-in-tengahpandemi-covid-19

I.Dahnial. 2017. Pkn Teacher Competency Analysis in Implementing the 2013 Curriculum in State Junior High School in Stabat District. JOURNAL OF THEMATICS Volume 6 No. 4 things. $34-36$

Lako, Andreas. 2004. Leadership and Organizational Performance Issues, Theories, and Solutions. Yogyakarta: Amara Books.

Suh understanding, Basic Concepts and Educational Supervision Techniques, (Jakarta: Rineka Cipta, 2000), p. 112

Santoso, J. T. 2013. Accounting Learning Strategies. Semarang: YSBJ KANTHIL.

Sudjana, N. 2004. Basics of Teaching and Learning Process. Bandung: Sinar Baru Algensido Offset.

Law Number 13 of 2003 concerning Manpower. Law Number 14 of 2005 concerning Teachers and Lecturers.

Law Number 20 of 2003 concerning the National Education System.

Wahjosumidjo, leadership of the School Principal (theoretical review and problems), (Jakarta: Raja Grafindo persada, 2005) 83. 